\title{
Pengaruh antara Iklim Organisasi dan Kepuasan Kerja dengan Organizatioanal Citizenship Behaviour Pada Guru MIN Se Kota Pekanbaru
}

\author{
Nurhasnawati \& Mhd Subhan \\ Universitas Islam Negeri Sulthan Syarif Kasim Pekanbaru, Indonesia \\ nurhasnawati.tarbiyah@yahoo.com \\ Mhd.subhan@uin-suska.ac.id
}

\begin{abstract}
This research aimed at investigating the influence of organizational climate and job satisfaction on organizational citizenship behavior of Islamic elementary school teachers in Pekanbaru. The population of this research was teachers of Islamic elementary schools in Pekanbaru. The sampling technique of this research was simple random sampling which consisted of 164 samples. This research used two instruments: organizational climate and job satisfaction instruments, and organizational citizenship behavior. The validity of data was conducted with 3 experts which consisted of one expert of primary education and 2 experts of educational management. The reliability of 3 instruments was organization climate with Cronbach Alpha 0.84, job satisfaction with Cronbach Alpha 0.77, and organizational citizenship behavior with Cronbach Alpha 0.81. The analysis of data used SPSS Software Version 22.0. The research findings demonstrated that the descriptive level of job satisfaction toward organizational citizenship behavior was intermediate. However, it was significantly difference from climate organization. In addition, the inferential analysis with multiple regression about the influence of organizational climate and job satisfaction on organizational citizenship was $80.8 \%$. It means that other factors was $19.2 \%$. Therefore, the principal required to establish a program to improve the influence the organizational climate and job satisfaction on organizational citizenship behavior of Islamic elementary school teachers in Pekanbaru.
\end{abstract}

Keywords: Organizational climate, job satisfaction, organizational citizenship behaviours

\section{A. Latar Belakang Masalah}

Dalam era globalisasi saat ini, persaingan dalam dunia pendidikan mengalami peningkatan. Apalagi dalam beberapa tahun kedepan Indonesia akan berpartisipasi dalam kancah persaingan bebas baik dalam bisnis juga dalam pendidikan. Menghadapi hal tersebut pendidikan Indonesia harus bereaksi dan sensitif untuk menyiapkan lulusan yang siap menghadapi persaingan.
Tantangan ini juga dihadapkan kepada instansi pendidikan dan sekolahsekolah, khususnya sekolah kejuruan. ${ }^{1}$

Guru merupakan faktor yang berpengaruh dalam pendidikan. Jika guru memiliki OCB maka guru mampu

\footnotetext{
${ }^{1}$ Yuniar dkk. Hubungan Kepuasan Kerja dan Resiliensi dengan Organizational Citizenship Behaviour (OCB) Pada Karyawan Kantor Pusat PT. BPD BALI. Jurnal Psikologi Undip Vol.9, No.1 2011.
} 
mengendalikan perilakunya sendiri atau memilih perilaku yang sesuai untuk kepentingan organisasi. Perilaku ini akan muncul karena memiliki perasaan sebagai anggota organisasi dan merasa puas bila melakukan sesuatu yang lebih bagi organisasi. Bersona dan Avilio menemukan pada beberapa penelitian bahwa salah satu faktor penting yang membentuk OCB adalah iklim organisasi. Iklim organisasi akan menentukan apakah seseorang dapat melaksanakan tugas dan tanggungjawab sesuai prosedur atau tidak. ${ }^{2}$

Setiap karyawan, baik guru maupun tenaga kependidikan memiliki tupoksi masing-masing. Guru misalnya, yang tugasnya tercantum jelas pada UU RI Nomor 14 Tahun 2005 Tentang Guru dan Dosen. Hal ini menjadi kewajiban bagi setiap individu untuk melaksanakan kewajiban mereka dengan baik. Dengan demikian mereka telah melaksankan tugas yang menjadi bagiannya dalam sebuah organisasi.

Oleh karena itu, guru-guru yang memiliki OCB sangat penting dalam usaha peningkatan mutu pendidikan ini khususnya mutu Sekolah. Guru yang memiliki OCB akan memberikan hal lebih untuk organisasi untuk lebih baik. Telah banyak pembuktian dalam dunia bisnis betapa OCB membantu organisasi berjalan lebih efektif. Hal ini juga dibuktikan secara empiris oleh Robbins dan Judge, yang menunjukkan bahwa organisasi yang mempunyai karyawan yang memiliki Organizasional Citizenship Behavior yang baik, akan memiliki kinerja yang baik. Selanjutnya menurut Landen (2001:53), OCB terbukti memberikan kontribusi positif terhadap kinerja karyawan secara keseluruhan serta

2 Brahmana, S.S. \& Sofyandi, H. Transformational Leadership dan Organization Citizenship Behavior di Utama. Laporan Penelitian. Tidak diterbitkan. 2007. efektifitas kerja karyawan dan organisasi. $^{3}$

Perilaku guru disekolah tidak terbentuk dengan sendirinya. Guru berinteraksi dengan murid, rekan kerja, dan juga pimpinan organisasi atau kepala sekolah. Kondisi kondusif dalam sekolah terlihat dengan bagaimana komunikasi dan hubungan antara warga sekolah. Dengan kondisi yang tidak kondusif akan berdampak kepada iklim yang kurang harmonis dan juga ketidak puasan kerja. Hal ini menjadi pertimbangan penting bagi kepala sekolah karena iklim organisasi yang tidak sehat dan kepuasan kerja yang rendah akan menggangu keefektifitasan kerja organisasi. Hal ini merupakan salah satu faktor menjaga kepuasan kerja, selain dari gaji, pekerjaan mereka, dan kesempatan untuk promosi. Kepuasan kerja merupakan faktor penting dalam kondisi internal organisasi. Dugaan jika kepuasan kerja guru tinggi akan berhubungan dengan sikap kerjanya, berdampak kepada iklim organisasi. Dengan kepuasan kerja yang tinggi dan iklim organisasi yang baik akan membentuk perilaku dimana guru siap memberikan usaha lebih diluar dari yang diwajibkan organisasi. Inilah yang disebut dengan OCB. ${ }^{4}$

Menurut pengamatan dan hasil observasi yang dilakukan peneliti pada beberapa Madsrasah Ibitidaiyah di Kota Pekanbaru menemukan fenomena pada survei awal antara lain; Guru hanya memberikan tugas kepada perserta didik sementara gurunya berbincang-bincang dikantor atau meninggalkan sekolah, Guru sengaja memperlambat masuk kelas, peserta didik bosan dengan

\footnotetext{
${ }^{3}$ Robbins, Stephen P. Perilaku Organisasi. Edisi Bahasa Indonesia. PT. Indeks. Jakarta. 2006.

${ }^{4}$ Vannecia dkk. Pengaruh Kepuasan Kerja Dan Loyalitas Kerja Terhadap Organizational Citizenship Behaviour Pada Karyawn PT. Surya Timur Jatim. AGORA Vol.1, No.1. 2013.
} 
pembelajaran yang diberikan guru, Guru (piket) enggan menggantikan guru yang berhalangan mengajar yang dikarenakan tidak ada honornya, Banyak guru kurang inovasi dan kreativitas dalam menyampaikan materi ajar, monoton, Guru enggan menjadi penanggung jawab acara-acara perpisahan, festival dan tetap menunjuk yang sudah biasa melakukannya, guru kurang ingin mempelajari hal-hal baru. Untuk mencapai prestasi tinggi memerlukan usaha lebih setiap pihak di organisasi sekolah. Usaha lebih yang diluar dari Job Description inilah yang dimaksud dengan perilaku Organizational Citizenship Behaviour (OCB) ${ }^{5}$

Sekolah-sekolah yang meraih prestasi di kancah lokal, nasional bahkan internasional pastinya tidak lepas dari peran serta guru sebagai penggerak organisasi. Untuk itu perlu dilakukan penelitian lebih lanjut mengenai fenomena ini. Apalagi guruguru Madrasah Ibtidaiyah Negeri yang masih ramai yang masih rendah kepuasan kerja dan mempengaruhi iklim organisasi. Begitu pula guru-guru yang memiliki OCB rendah maka akan memberikan dampak kepada kemajuan sekolah mereka. ${ }^{6}$

Iklim Organisasi dan kepuasan kerja harus diperhatikan karena dapat mempengaruhi perilaku organisasi guru. Bila organisasi memiliki guru-guru yang memiliki perilaku OCB, maka kinerja organisasi tersebut akan lebih baik dan efektif. Karena itulah OCB ini sangat penting ditanamkan pada guru MI yang merupakan bagian penting

\footnotetext{
5 Afriani, Fitri. Pengaruh Iklim Organisasi terhadap Kepuasan Kerja Pegawai pada Kantor Kecamatan Kepenuhan Hulu. Jurnal Mahasiswa Prodi SI Manajemen, 1 (1), h:1-23. 2013.

${ }^{6}$ Herman. Pengaruh Iklim Organisasi dan Kepuasan Kerja Terhadap Kinerja Guru.Jurnal Administrasi Pendidikan Pascasarjana Universitas Syiah Kuala Vol4, No.2. 2014.
}

dalam organisasi sekolah. Apalagi masih belum meneliti tentang iklim organisasi dan kepuasan kerja dengan OCB pada guru MI. Dari fenomena diatas maka sangat penting meneliti tentang pengaruh antara iklim organisasi dan kepuasan kerja dengan organizatioanal citizenship behaviour pada Guru MIN Se Kota Pekanbaru”.

\section{B. Tinjauan Pustaka}

\section{Organizational Citizenship Behaviour \\ 1.1 Pengertian Organizational Citizenship Behaviour}

Manusia adalah pelaku utama dalam organisasi, baik sebagai objek maupun sebagai subjek. Begitu banyak bentuk perilaku manusia dalam organisasi, salah satunya adalah perilaku prososial dilingkungan kerja yang diarahkan kepada sesama pegawai atau kepada organisasi itu sendiri, perilaku tersebut dinamakan Organizational Citizenship Behaviour (OCB).

OCB dapat didefinisikan sebagai perilaku-perilaku pegawai yang diluar tugas. Contoh-contohnya adalah 'sikap sebagai pernyataan konstruktif mengenai departemen, pengungkapan minat pribadi dalam pekerjaan orang lain, saran-saran untuk peningkatan, pelatihan pegawai baru, rasa hormat untuk semangat dan tulisan auran pemeliharaan bangunan, peduli terhadap properti perusahaan, serta ketepatan waktu dan kehadiran di atas tingkat yang dapat dilaksanakan. ${ }^{7}$

Fakta bahwa Organizational Citizenship Behaviour (OCB) tidak mendapatkan imbalan dari organisasi atau perusahaan misalnya bonus atau kenaikan gaji adalah hal penting, karena itu berarti bahwa OCB terjadi tanpa

\footnotetext{
7 Kaswan. Sikap Kerja: Dari Teori dan Implementasi sampai Bukti. Alfabeta. Bandung. 2015 .
} 
didasari harapan untuk mendapatkan imbalan ketika individu melakukan pekerjaan lebih untuk organisasi atau perusahaan. OCB juga dapat diartikan sebagai pekerjaan bebas yang dilakukan oleh individu secara spontan untuk menunjang kelangsungan organisasi atau dengan kata lain OCB muncul tanpa adanya perintah dari pihak manapun. ${ }^{8}$

Berdasarkan uraian diatas menjelaskan bahwa Organization Citizenship Behavior (OCB) adalah perilaku baik yang diluar dari kewajiban pekerjaan formal namun mendukung berfungsinya organisasi lebih efektif.

\subsection{Faktor-faktor mempengaruhi Organizational Citizenship Behaviour \\ Faktor-faktor yang}

mempengaruhi OCB cukup kompleks dan saling terkait satu sama lain. Diantara faktor-faktor tersebut yang memberikan dampak yang cukup signifikan sehingga perkembangnya perlu untuk diperhatikan yaitu a. Budaya dan Iklim Organisasi, b. Kepribadian dan suasana hati (mood), c. Persepsi terhadap Perceived Organizational Support, d. Persepsi terhadap kualitas hubungan atau interaksi atasan bawahan, e. Masa Kerja dan f. Jenis Kelamin (gender).

\subsection{Indikator Organizational Citizenship Behaviour}

Terdapat lima dimensi OCB adalah sebagai berikut a. Altruism, b. Conscientiousness, c. Sportmanship, d. Courtessy dan e. Civic Virtue.

\footnotetext{
${ }^{8}$ Eddy Triyono. Determinasi Iklim Organisasi Terhadap Golongan Kepangkatan dalam Pengembangan Profesional Dosen, dalam Jurnal TEKNIS, Volume 10, Nomor 2, Agustus 2015 : $102-106$, Politeknik Negeri Semarang, Semarang. 2015.

9 Triatna, Cepi. Perilaku Organisasi dalam Pendidikan. Bandung:ROSDA. 2015.
}

\section{Iklim Organisasi}

\subsection{Pengertian Iklim Organisasi}

Studi tentang iklim organisasi dirintis oleh Kurt Lewin di tahun 1930an, ketika ia mencoba menghubungkan perilaku manusia dengan lingkungannya. Dalam studi tersebut Lewin memperkenalkan istilah 'atmosfir' (atmosphere) yang terkait dengan 'medan psikologi (psychological field) sebagaimana dapat dibaca dalam kutipan berikut ini:

Untuk memaparkan ciri-ciri 'medan psikologis', kita harus memperhitungkan hal-hal khusus, seperti tujuan, stimuli, kebutuhan, hubungan sosial maupun ciri-ciri yang bersifat lebih umum, seperti atmosfir (misalnya, atmosfir yang ramah, tegang, atau permusuhan) atau tingkat kebebasan yang ada. Ciri-ciri medan ini secara keseluruhan sama pentingnya dalam ilmu psikologi, bila dibandingkan misalnya dengan medan berat (field of gravity) di dalam ilmu fisika klasik dalam penjelasan peristiwa-peristiwa. Atmosfir psikologis adalah kenyataan-kenyataan empiris dan merupakan fakta-fakta yang dapat diuraikan secara ilmiah. ${ }^{10}$

Iklim organisasi merupakan kualitas llingkungan internal organisasi yang secara relatif terus berlangsung, dialami oleh anggota organisasi, mempengaruhi perilaku mereka dan dapat dilukiskan dalam pengertian satu set karakteristik atau sifat organisasi. ${ }^{11}$

\footnotetext{
10 Prihatsanti, U. Hubungan Antara Iklim Organisasi Dan Organizational Citizenship Behavior (OCB) Pada Guru SD Negeri Di Kecamatan Mojolaban Sukoharjo. Jurnal Psikologi Undip Vol. 7, No.1, April 2010. 1117. 2010.

${ }^{11}$ Dharing Meylandani. Hubungan Antara Iklim Organisasi Dan Organizational Citizens Behavioral (Ocb) Pada Perawat Rsud Kanjuruhan Kepanjen Kabupaten Malang, dalam Jurnal Online Vol.1, No.1. 2013.
} 
Iklim organisasi sebagai koleksi dan pola lingkungan yang menentukan munculnya motivasi serta berfokus pada persepsi-persepsi yang masuk akal atau dapat dinilai, sehingga mempunyai pengaruh langsung terhadap kinerja anggota organisasi. Iklim organisasi merupakan kualitas lingkungan internal organisasi yang secara relatif terus berlangsung, dialami oleh anggota organisasi dan mempengaruhi perilaku mereka serta dapat dilukiskan dalam satu set karateristik atau sifat organisasi atau lembaga. ${ }^{12}$

Dari beberapa pendapat diatas dapat disimpulkan bahwa Iklim organisasi merupakan kualitas llingkungan internal organisasi yang secara relatif terus berlangsung, dialami oleh anggota organisasi, mempengaruhi perilaku mereka dan dapat dilukiskan dalam pengertian satu set karakteristik atau sifat organisasi.

\subsection{Faktor yang mempengaruhi Iklim Organisasi}

Dalam lingkungan organisasi iklim organisasi berubah secara dinamis. Situasi yang baik dapat berubah dalam keadaan tertentu sehingga kondisi internal organisasi terasa buruk. Hal ini bisa dirasakan anggota organisasi bila ada masalah dalam lingkungan kerja mereka. Jika terus dibiarkan suasana tidak baik ini akan mempengaruhi motivasi, kepuasan dan prestasi kerja. Dengan kata lain akan berdampak buruk pada kinerja organisasi.

Ada beberapa faktor yang mempengaruhi iklim organisasi ${ }^{13}$ yaitu:

1. Individual initiative, yaitu tingkat tanggung jawab dan kemandirian yang dimiliki tiap anggota

\footnotetext{
${ }^{12} \mathrm{Ibid}$

${ }^{13}$ Ibid
}

2. Risk tolerance, yaitu tingkat resiko yang boleh atau mungkin dipikul oleh anggotanya untuk mendorong mereka menjadi agresif, inovatif, dan berani mengamil resiko

3. Integration, yaitu tingkat unitunit kerja dalam organisasi yang mendorong untuk beroperasi dalam koordinasi yang baik

4. Management support, yaitu tingkat kejelasan komounikasi, bantuan dan dukungan yang disediakan manajemen terhadap unit kerja di bawahnya

5. Control, yaitu sejumlah aturan/peraturan dan sejumlah pengawasan yang digunakan untuk mengtur dan mengawasi perilaku karyawan

6. Identity, yaitu tingkat identifikasi diri tiap anggota organisasi secara keseluruhan melebihi group kerja atau bidang profesi masing-masing

7. Rewards, yaitu tingkat alokasi dan penghargaan (promosi jabatan dan honor) berdasarkan kinerja pegawai sebagai lawsan dari senioritas, anakmas dan lain-lain

8. Conflict tolerance, yaitu tingkat toleransi terhadap konflik dan kritik keterbukaan yang muncul dalam organisasi

9. Communications patterrus, yaitu tingkat keterbatasan komunikasi dalam organisasi yang sesuai otorisasi pada hirarki formal.

\subsection{Indikator Iklim Organisasi}

karakteristik atau komponen iklim organisasi mempengaruhi motivasi anggota organisasi untuk berperilaku tertentu. Menurutnya terdapat 6 komponen untuk mengukur hal tersebut, yaitu a. Struktur (Structure), b. Standarstandar (Standards), c. Tanggung jawab 
(Responsibility), d. Penghargaan (Recognition), e. Dukungan (Support) dan f. Komitmen (Commitment). ${ }^{14}$

\section{Kepuasan Kerja \\ 1.1 Pengertian Kepuasan Kerja}

Salah satu faktor yang perlu mendapatkan perhatian dari pimpinan organisasi atau perusahaan dalam mengelola sumber daya manusia adalah masalah kepuasan kerja karyawan. Karena tanpa merasakan kepuasan kerja, karyawan kurang memberikan sumbangan yang optimal bagi pencapaian tujuan perusahaan. "“ Kepuasan kerja yang tinggi tidak dapat dicapai dengan sendirinya, tetapi perlu diupayakan dengan memberikan perhatian terhadap faktor-faktor yang berpengaruh terhadap kepuasan kerja karyawan.

Sedangkan menurut Robbins kepuasan kerja merupakan suatu sikap umum terhadap pekerjaan seseorang, selisih antara banyaknya ganjaran yang diterima seorang pekerja dan banyaknya yang mereka yakini apa yang seharusnya mereka terima, kepuasan terjadi apabila kebutuhan-kebutuhan individu sudah terpenuhi dan terkait dengan derajat kesukaran dan ketidaksukaran diikaitkan dengan karyawan yang erat kaitanyadengan imbalan-imbalan yang mereka yakini akan mereka terima setelah melakukan sebuah pengorbanan. ${ }^{15}$

Dari uraian diatas dapat disimpulkan bahwa kepuasan kerja adalah suatu perasaan seseorang terhadap pekerjaannya, dimana ia akan merasa puas apabila ada kesesuaian antara kemampuan, keterampilan dan harapannya dengan pekerjaan yang ia

\footnotetext{
${ }^{14}$ Ayudiarini, Natassia. Pengaruh Iklim Organisasi dan Pengembangan Karir Terhadap

Kepuasan Kerja. Gunadarma University EPaper,1 (2) h:1-16. 2010.

${ }^{15}$ Ibid
}

hadapi. Kepuasan akan menghasilkan hasil yang semaksimal mungkin antara interaksi manusia dengan lingkungan kerjanya. Dengan demikian ia akan memberikan sumbangan yang optimal untuk mencapai tujuan perusahaan.

\subsection{Faktor-faktor mempengaruhi Kerja \\ yang}

Menurut horald E.Burt yang dikutip $^{16}$ ada beberapa faktor yang mempengaruhi kepuasan kerja yaitu:

1. Faktor hubungan antar karyawan, antara lain hubungan antara pimpinan dengan pegawai, kondisi fisik dan situasi kerja, sugesti dari teman kerja

2. Faktor individual, yang berhubungan dengan sikap orang terhadap pekerjaannya, umur orang saat kerja, jenis kelamin

3. Faktor-faktor luar antara lain keadaan keluarga karyawan/ pegawai, rekreasi, pendidikan.

Pada dasarnya makin positif sikap kerja makin besar pula kepuasan kerja, untuk itu berbagai indikator dari kepuasan kerja perlu memperoleh perhatian khusus agar pekerja dapat meningkatkan kinerjanya. Pada umumnya seseorang merasa puas dengan pekerjaanya karena berhasil dan memperoleh penilaiaan yang adil dari pimpinannya.

\subsection{Indikator Kepuasan Kerja}

Ada beberapa dimensi kepuasan kerja yang dapat digunakan untuk mengukur kepuasan kerja. Dimensi itu adalah antara lain a. Pekerjaan itu sendiri (Work It Self), b. Atasan (supervision), c. Teman sekerja (Workers), d. Promosi (promotion) dan Gaji (pay). ${ }^{17}$

\footnotetext{
${ }^{16}$ As'ad, Muhammad. Psikologi Industri. Liberty. Yogyakarta. 2004.

${ }^{17}$ Ibid
} 
Dari uraian diatas dapat disimpulkan bahwa kepuasan kerja adalah perasaan yang dirasakan individu akibat dari penilaian kerja atau pengalaman kerja yang meliputi aspekaspek: pekerjaan itu sendiri, penyelia, teman sekerja, promosi dan gaji.

\section{Hubungan Iklim Organisasi Dan Kepuasan Kerja Terhadap Organizational Citizenship behaviour (OCB)}

Kepuasan kerja adalah perasaan positif yang dirasakan karyawan berkaitan dengan pekerjaannya. Selain itu, karyawan yang puas mungkin menjadi lebih bangga melebihi tuntutan tugas karena mereka ingin membalas pengalaman positif mereka. ${ }^{18}$

Kepuasan kerja diartikan sebagai tanggapan emosional seseorang terhadap aspek-aspek di dalam atau pada keseluruhan pekerjaannya. Keadaan emosional atau sikap seseorang tersebut akan diperlihatkan dalam bentuk tanggung jawab, perhatian, serta perkembangan kinerjanya. Kepuasan kerja dapat muncul karena kerja yang secara mental menantang, ganjaran yang pantas, kondisi kerja yang mendukung, rekan kerja yang mendukung, kesesuaian kepribadian dengan pekerjaan. Berdasarkan penjelasan ini dapat dilihat bahwa gaji bukanlah faktor mutlak yang mendasari orang puas atau tidak puas. Menurut teori dua faktor dari Herzberg, pada umumnya karyawan mengidentifikasikan kepuasan dengan faktor internal dalam diri mereka, seperti prestasi yang dicapai dan promosi. Sebaliknya karyawan akan mengidentifikasi ketidakpuasan kerja pada faktor-faktor eksternal seperti gaji, dukungan teman dan penyelia. ${ }^{19}$

\footnotetext{
${ }^{18}$ Ibid

${ }^{19}$ Ulfiani. Kepuasan Kerja dan Organizational Citizenship Behaviour Pada Guru Madrasah
}

\section{E. Metodelogi Penelitian}

Penelitian ini menggunakan penelitian deskriptif kuantitatif regresi berganda. Menurut Sugiyono (2015) Metode deskriptif kuantitatif analisis regresi berganda digunakan untuk memeriksa, mencatat, menganalisis, dan menginterpretasikan variabel antara iklim organisasi dan kepuasan kerja dengan organizatioanal citizenship behaviour pada Guru.

Teknik persampelan menggunakan Simple random sampling. Pengambilan sampel dengan Simple random sampling ini dengan tujuan memberikan kesempatan sama kepada semua individu pada masing-masing kluster untuk memiliki kemungkinan atau peluang terambil sebagai sampel. ${ }^{20}$ Sampel nya Seramai 164 Guru MIN Pekanbaru.

Penelitian ini menggunakan angket/kuesioner yaitu angket iklim organisasi, angket kepuasan kerja dan angket organizatioanal citizenship behaviour. Angket telah di validasi oleh 3 tim pakar yaitu 1 pakar bidang sekolah dasar dan 2 pakar bidang manajemen pendidikan. Bagi uji coba reliabilitas menggunakan sampel 30 guru Madrasah Ibtidaiyah dengan didapati alpha Cronbach yaitu instrument iklim organisasi dengan Alpha Cronbanch adalah .84. Sedangkan kepuasan kerja didapati Alpha Cronbanch adalah .77 dan instrument antara organizational citizenship behaviour didapati Alpha Cronbanch adalah .81. Teknik analisis data menggunakan Software SPSS. 22 Version.

Aliyah Madani Alaudin Paopao Gowa Sulawesi Selatan. Jurnal Analisa Vol. 21, No.1. 2014.

20 Yusuf, A.M. "Metodologi Penelitian: Kuantitatif, Kualitatif dan Penelitian Gabungan”. Padang: UNP Press. 2013. 


\section{F. Hasil Penelitian}

\section{Dapatan Analisis Deskripsi}

Data penelitian ini meliputi 3 variabel, yaitu variabel iklim organisasi $\left(\mathrm{X}_{1}\right)$, kepuasan kerja $\left(\mathrm{X}_{2}\right)$ dan Organizational Citizenship Behaviour (OCB) (Y). Secara singkat dapat dinyatakan bahwa deskripsi data ini mengungkapkan informasi tentang ratarata (mean), nilai tengah (median), angka yang sering muncul (modus), simpangan baku (standar deviasi), keragaman (variansi), rentang data (range), nilai terendah (minimum), nilai tertinggi (maximum).

Berikut ini dijelaskan perhitungan deskripsi data untuk masing-masing variabel.

\subsection{Deskripsi Data Organizational Citizenship Behaviour (OCB) (Y) \\ Deskriptif merupakan suatu cara} menggambarkan persoalan yang berdasarkan data yang dimiliki yakni dengan cara menata data tersebut sedemikian rupa sehingga dengan mudah dapat dipahami tentang karakteristik data, dijelaskan dan berguna untuk keperluan selanjutnya. Berdasarkan hasil perhitungan terhadap data Organizational Citizenship Behaviour (OCB) diperoleh sebaran skor OCB guru MIN Se Kota Pekanbaru disajikan dalam daftar distribusi frekuensi dengan lima kategori yaitu sangat tinggi, tinggi, sedang, rendah, dan sangat rendah. Selanjutnya penyebaran distribusi frekuensi data Iklim Organisasi guru MIN Se Kota Pekanbaru dapat dilihat pada tabel berikut ini :

Berdasarkan tabel 1 diketahui distribusi frekuensi skor Organizational Citizenship Behaviour (OCB) terdiri dari lima kelas interval. Skor tertinggi Organizational Citizenship Behaviour (OCB) terdapat pada interval 84-88 sebanyak 72 orang atau $43,90 \%$. Dengan demikian skor Organizational Citizenship Behaviour (OCB) Guru MIN Se Kota Pekanbaru berada dalam kategori sedang.

Tabel 1

Distribusi Frekuensi Skor Organizational Citizenship Behaviour (OCB) (Y)

\begin{tabular}{|c|c|c|c|}
\hline \multirow{2}{*}{ Kategori } & \multirow{2}{*}{ Kelas Interval } & \multicolumn{2}{|c|}{ Frekuensi } \\
\cline { 3 - 4 } & $74-78$ & Absolut & Relatif (\%) \\
\hline Sangat Rendah & $79-83$ & 6 & 3,66 \\
\hline Rendah & $84-88$ & 72 & 12,80 \\
\hline Sedang & $89-93$ & 49 & 43,90 \\
\hline Tinggi & $94-98$ & 16 & 29,88 \\
\hline Sangat Tinggi & & 164 & 9,76 \\
\hline Jumlah & &
\end{tabular}




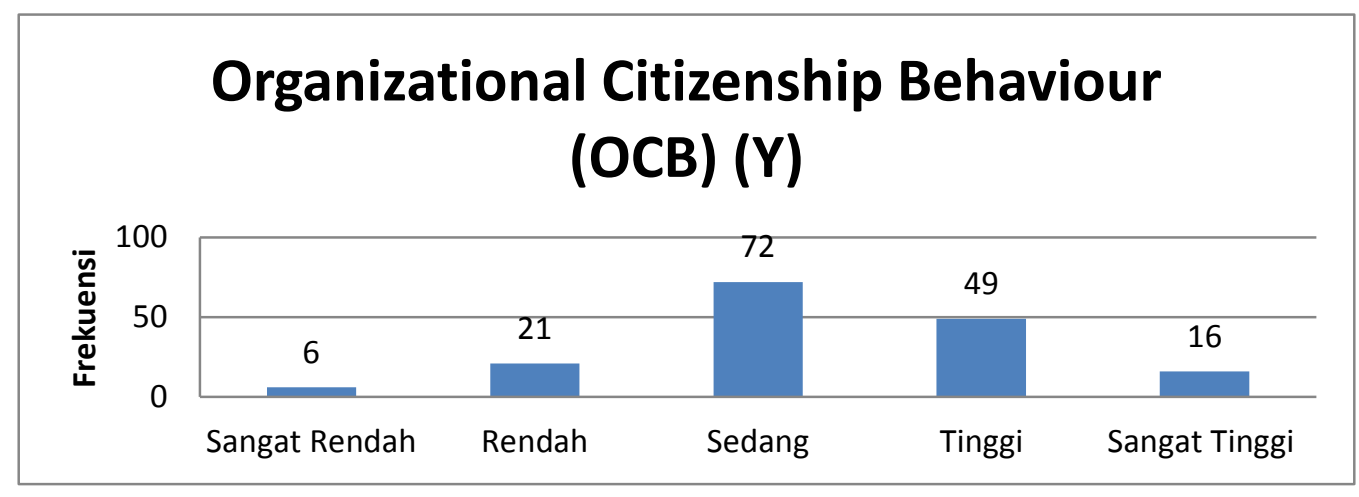

ar 1 Diagram Batang Frekuensi Skor Variabel Y

Gamb

\subsection{Deskripsi Data Iklim Organisasi (X1)}

Deskripsi data iklim organisasi diperoleh sebaran skor Iklim Organisasi guru MIN Se Kota Pekanbaru disajikan dalam daftar distribusi frekuensi dengan lima kategori yaitu sangat tinggi, tinggi, sedang, rendah, dan sangat rendah. Selanjutnya penyebaran distribusi frekuensi data Iklim Organisasi guru
MIN Se Kota Pekanbaru dapat dilihat pada tabel berikut ini :

Berdasarkan tabel 2 diketahui distribusi frekuensi skor Iklim Organisasi terdiri dari lima kelas interval. Skor tertinggi Iklim Organisasi guru terdapat pada interval 79-83 sebanyak 63 orang atau $38,41 \%$. Dengan demikian skor Iklim Organisasi guru MIN Se Kota Pekanbaru berada dalam kategori sedang.

Tabel 2

Distribusi Frekuensi Skor Iklim Organisasi (X1)

\begin{tabular}{|c|c|c|c|}
\hline \multirow[b]{2}{*}{ Kategori } & \multirow[b]{2}{*}{ Kelas Interval } & \multicolumn{2}{|c|}{ Frekuensi } \\
\hline & & Absolut & Relatif (\%) \\
\hline Sangat Rendah & $69-73$ & 6 & 3,66 \\
\hline Rendah & $74-78$ & 29 & 17,68 \\
\hline Sedang & $79-83$ & 63 & 38,41 \\
\hline Tinggi & $84-89$ & 49 & 29,88 \\
\hline Sangat Tinggi & $90-95$ & 17 & 10,37 \\
\hline \multicolumn{2}{|c|}{ Jumlah } & 164 & 100 \\
\hline
\end{tabular}

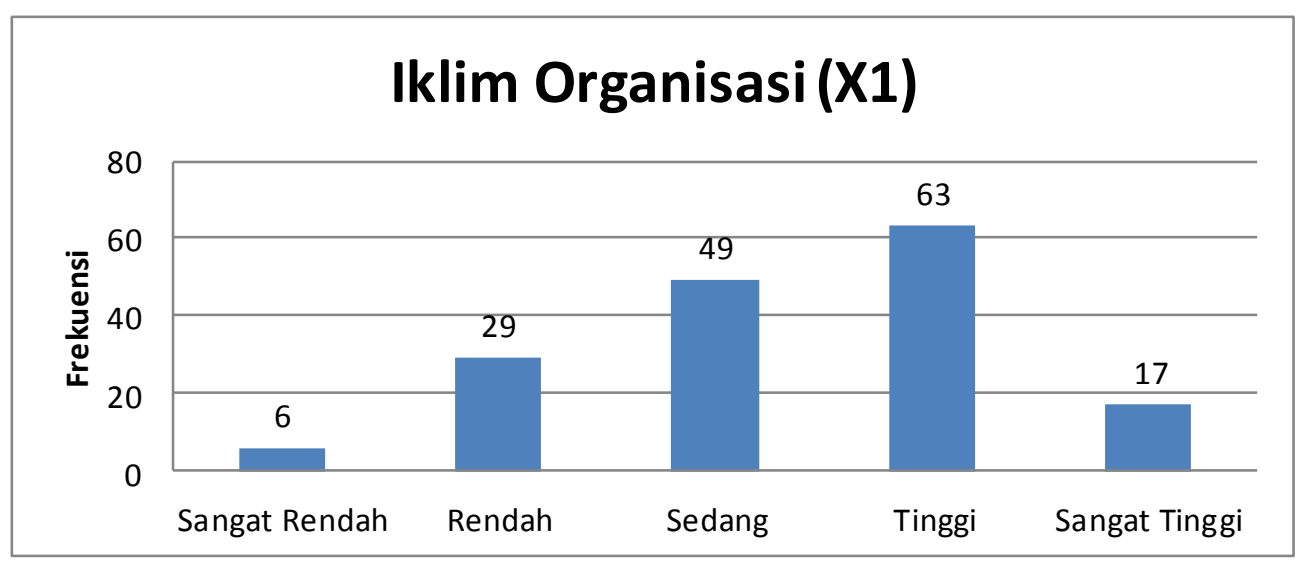




\section{Gambar 2 Diagram Batang Frekuensi Skor Variabel X1}

\subsection{Deskripsi Data Kepuasan}

\section{Kerja (X2)}

Deskripsi data kepuasan kerja diperoleh sebaran skor kepuasan kerja guru MIN Se Kota Pekanbaru disajikan dalam daftar distribusi frekuensi dengan lima kategori yaitu sangat tinggi, tinggi, sedang, rendah, dan sangat rendah. Selanjutnya penyebaran distribusi frekuensi data kepuasan kerja guru MIN Se Kota Pekanbaru dapat dilihat pada tabel berikut ini:
Berdasarkan tabel 3 diketahui distribusi frekuensi skor kepuasan kerja terdiri dari lima kelas interval. Skor tertinggi kepuasan kerja guru terdapat pada interval 80-84 sebanyak 67 orang atau 40,85\%. Dengan demikian skor kepuasan kerja guru MIN Se Kota Pekanbaru berada dalam kategori sedang.

Tabel 3

Distribusi Frekuensi Skor Kepuasan Kerja (X2)

\begin{tabular}{|c|c|c|c|}
\hline \multirow[b]{2}{*}{ Kategori } & \multirow[b]{2}{*}{ Kelas Interval } & \multicolumn{2}{|c|}{ Frekuensi } \\
\hline & & Absolut & Relatif (\%) \\
\hline Sangat Rendah & $70-74$ & 7 & 4,27 \\
\hline Rendah & $75-79$ & 46 & 28,05 \\
\hline Sedang & $80-84$ & 67 & 40,85 \\
\hline Tinggi & $85-89$ & 30 & 18,29 \\
\hline Sangat Tinggi & $90-94$ & 14 & 8,54 \\
\hline $\mathbf{J u}$ & & 164 & 100 \\
\hline
\end{tabular}

\section{Kepuasan Kerja (X2)}

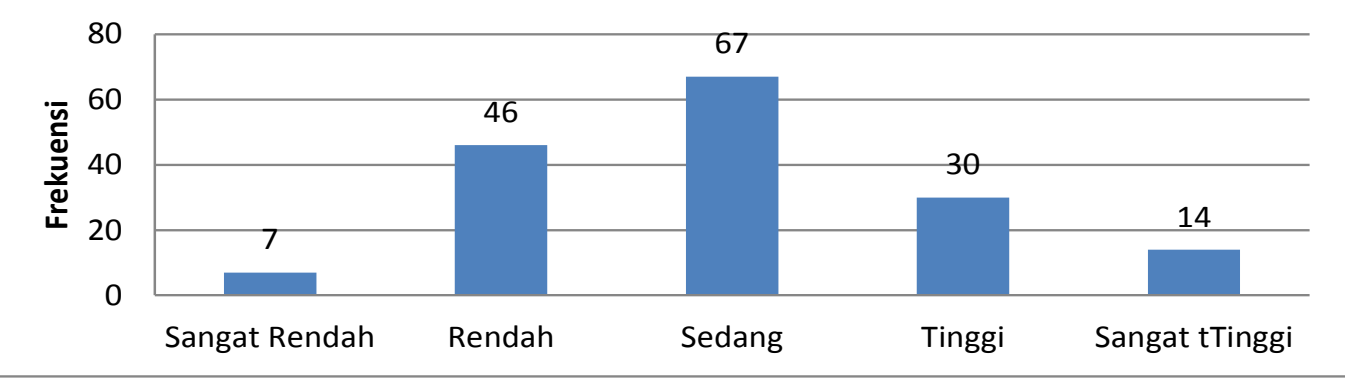

bar 3 Diagram Batang Frekuensi Skor Variabel X2

2. Dapatan Analisis Inferensi

\subsection{Pengujian} Analisis

Analisis data untuk menguji hipotesis penelitian dilakukan dengan menggunakan analisis statistik parametik, yaitu analisis regresi berganda. Sebelum melakukan uji statistika parametrik terlebih dahulu peneliti melalukan uji persyaratan analisis yaitu uji normalitas. Uji normalitas dilakukan untuk mengetahui normal tidaknya sebaran data yang akan dianalisis. Data tersebut meliputi variabel Organizational Citizenship Behaviour (OCB) (Y), Iklim Organisasi $\left(\mathrm{X}_{1}\right)$ dan kepuasan kerja $\left(\mathrm{X}_{2}\right)$. Uji normalitas menggunakan SPSS versi 22.

Uji normalitas data pada penelitian ini menggunakan uji Kolmogorov-smirnov, dengan taraf 
signifikan yang digunakan sebagai aturan untuk menerima atau menolak pengujian normalitas atau ada tidaknya suatu distribusi data $\alpha=0,05$. Untuk menerima atau menolak hipotesis dengan cara membandingkan nilai signifikan variabel dengan $\alpha=0,05$. Adapun kaidah keputusan, data dinyatakan berdistribusi normal jika nilai signifikan $>\alpha=0,05$. Hasil pengujian normalitas dari ketiga variabel dapat dilihat pada tabel dibawah ini :

Kenormalan data dalam penelitian ini dapat diketahui dari uji normalitas Kolmogorov-Smirnov dari masing-masing variabel. Untuk melakukan pengujian normalitas data penelitian diperlukan hipotesis sebagai berikut :

$\mathrm{H}_{\mathrm{o}}$ : data berdistribusi normal

$\mathrm{H}_{\mathrm{a}}$ : data tidak berdistribusi normal

Terlihat dari tabel 4 pada kolom sig, diperoleh hasil signifikansi variabel Organizational Citizenship Behaviour (OCB) (Y) berdistribusi normal, karena nilai sig lebih besar dari nilai alpa $(0,340>0,05)$, variabel iklim organisasi $\left(\mathrm{X}_{1}\right)$ berdistribusi normal karena sig lebih besar dari nilai alpha $(0,200>$ $0,05)$, dan variabel kepuasan kerja $\left(\mathrm{X}_{2}\right)$ juga berdistribusi normal, karena nilai sig lebih besar dari nilai alpa $(0,232>$ $0,05)$. Nilai signifikansi masing-masing variabel ini > 0,05 yang berarti bahwa $\mathrm{H}_{\mathrm{o}}$ diterima atau data dari masingmasing variabel berdistribusi normal.

Dengan demikian, persyaratan analisis korelasi terpenuhi.

\subsection{Pengujian Hipotesis Penelitian}

Sesuai dengan pengujian hipotesis pada kerangka teoritik, maka akan dilakukan pengujian hipotesis yaitu Korelasi berganda iklim organisasi (X1) dan kepuasan kerja (X2) secara bersama-sama dengan Organizational Citizenship Behaviour (OCB) (Y). Teknik statistik yang digunakan untuk mengetahui hubungan antara variabelvariabel tersebut adalah teknik statistik korelasi product moment.

Korelasi produk moment menggunakan korelasi linier secara berganda. Teknik ini digunakan untuk menguji besarnya kontribusi dari variabel independen iklim organisasi (X1) dengan Organizational Citizenship Behaviour (OCB) (Y), besarnya kontribusi dari variabel independen kepuasan kerja (X2) dengan Organizational Citizenship Behaviour (OCB) (Y), besarnya kontribusi dari variabel independent iklim organisasi (X1) dan kepuasan kerja (X2) secara bersama-sama dengan variabel dependen Organizational Citizenship Behaviour (OCB) (Y).

Hipotesis yang disajikan adalah terdapat hubungan yang positif antara iklim organisasi (X1) dan kepuasan kerja (X2) secara bersama-sama dengan Organizational Citizenship Behaviour (OCB) guru (Y). Regresi linier akan disajikan pada tabel 5 di bawah ini :

\section{Tabel 4}

\section{Pengujian Normalitas Iklim Organisasi, Kepuasan Kerja terhadap Organizational Citizenship Behaviour (OCB) Tests of Normality}

\begin{tabular}{|l|r|r|r|r|r|r|}
\hline & \multicolumn{3}{|c|}{ Kolmogorov-Smirnov $^{\mathrm{a}}$} & \multicolumn{3}{|c|}{ Shapiro-Wilk } \\
\cline { 2 - 7 } & \multicolumn{1}{|c|}{ Statistic } & \multicolumn{1}{c|}{ Df } & \multicolumn{1}{c|}{ Sig. } & Statistic & \multicolumn{1}{c|}{ df } & \multicolumn{1}{c|}{ Sig. } \\
\hline Organizational_Citizens & .073 & 164 & $.340^{*}$ & .972 & 164 & .203 \\
hip_Behaviour(OCB) & .046 & 164 & $.200^{*}$ & .989 & 164 & .341 \\
Iklim_Organisasi & & & & & & \\
\hline
\end{tabular}




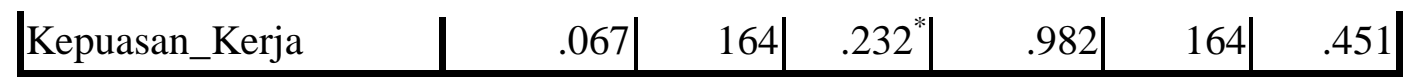

\section{Tabel 5}

Hasil uji regresi linier Iklim Organisasi (X1) dan Kepuasan Kerja (X2) dengan

Organizational Citizenship Behaviour (OCB) guru (Y).

Coefficients $^{\mathrm{a}}$

\begin{tabular}{|c|c|c|c|c|c|}
\hline \multirow[b]{2}{*}{ Model } & \multicolumn{2}{|c|}{$\begin{array}{c}\text { Unstandardized } \\
\text { Coefficients }\end{array}$} & \multirow{2}{*}{$\begin{array}{c}\begin{array}{c}\text { Standardized } \\
\text { Coefficients }\end{array} \\
\text { Beta }\end{array}$} & \multirow[b]{2}{*}{$\mathrm{t}$} & \multirow[b]{2}{*}{ Sig. } \\
\hline & B & Std. Error & & & \\
\hline 1 (Constant) & 0.052 & .166 & & .311 & .000 \\
\hline Kepuasan_Kerja & .164 & .064 & .166 & 2.565 & .010 \\
\hline Iklim_Organisasi & 1.153 & .072 & 1.035 & 15.956 & .000 \\
\hline
\end{tabular}

Dari tabel 5 di dapat persamaan regresinya adalah sebagai berikut $\ddot{\mathrm{Y}}=$ $0.052+1,153 \mathrm{X}_{1}+0,164 \mathrm{X}_{2}$. Hasil statistik tersebut menunjukkan bahwa setiap kenaikkan satu satuan iklim organisasi dan kepuasan kerja akan diikuti kenaikan Organizational Citizenship Behaviour (OCB) guru sebesar $1,153 \mathrm{X}_{1}$ dan $0,164 \mathrm{X}_{2}$ pada kostanta 0.052 pada guru MIN Se Kota Pekanbaru.

Untuk uji koefisien determinasi antara iklim organisasi (X1) dan kepuasan kerja (X2) secara bersamasama dengan Organizational Citizenship Behaviour (OCB) guru (Y) dapat dilihat pada tabel 17 di bawah ini :

Dari tabel 17 di atas didapat kekuatan hubungan antara iklim organisasi (X1) dan kepuasan kerja (X2) secara bersama-sama dengan Organizational Citizenship Behaviour (OCB) guru (Y) sebesar 0,899. Dari tabel diatas maka dapat dinyatakan bahwa kekuatan hubungan antara variabel dinyatakan sangat kuat. Kemudian untuk koefisien determinasi $\left(r^{2}\right)$ pada tabel di atas variabel Organizational Citizenship Behaviour (OCB) guru (Y) dipengaruhi oleh iklim organisasi (X1) dan kepuasan kerja (X2) sebesar 0,808 atau 80,8\% sedangkan sisanya $19,2 \%$ dipengaruhi oleh faktor lain. Dari penelitian ini dapat dijelaskan bahwa untuk meningkatkan Organizational Citizenship Behaviour (OCB) guru mutlak diperlukan peningkatan iklim organisasi dan kepuasan kerja baik dari segi materiil maupun inmateril. Dengan kata lain semakin baik iklim organisasi dan kepuasan kerja maka akan semakin baik pula tingkat Organizational Citizenship Behaviour (OCB) gurunya, demikian pula sebaliknya semakin rendah iklim organisasi dan kepuasan kerjanya, maka akan semakin turun tingkat Organizational Citizenship Behaviour (OCB) guru tersebut.

Pola hubungan ketiga variabel penelitian dapat digambarkan seperti :

Tabel 6

Hasil uji kekuatan antara variabel Iklim Organisasi (X1) dan kepuasan kerja (X2) dengan Organizational Citizenship Behaviour (OCB) Guru (Y)

Model Summary ${ }^{b}$

\begin{tabular}{|l|l|l|l|l|l|}
\hline Model & $\mathrm{R}$ & $\mathrm{R}$ & Adjusted & Std. Error & \\
\hline
\end{tabular}




\begin{tabular}{|r|r|r|r|r|r|r|r|r|r|}
\hline & & Square & R Square & $\begin{array}{c}\text { of the } \\
\text { Estimate }\end{array}$ & $\begin{array}{c}\text { R } \\
\text { Square } \\
\text { Change }\end{array}$ & F Change & df1 & $\begin{array}{c}\text { Sig. F } \\
\text { df } \\
\text { Change }\end{array}$ \\
\hline 1 & $.899^{\mathrm{a}}$ & .808 & .805 & .12965 & .808 & 338.153 & 2 & 161 & .000 \\
\hline
\end{tabular}

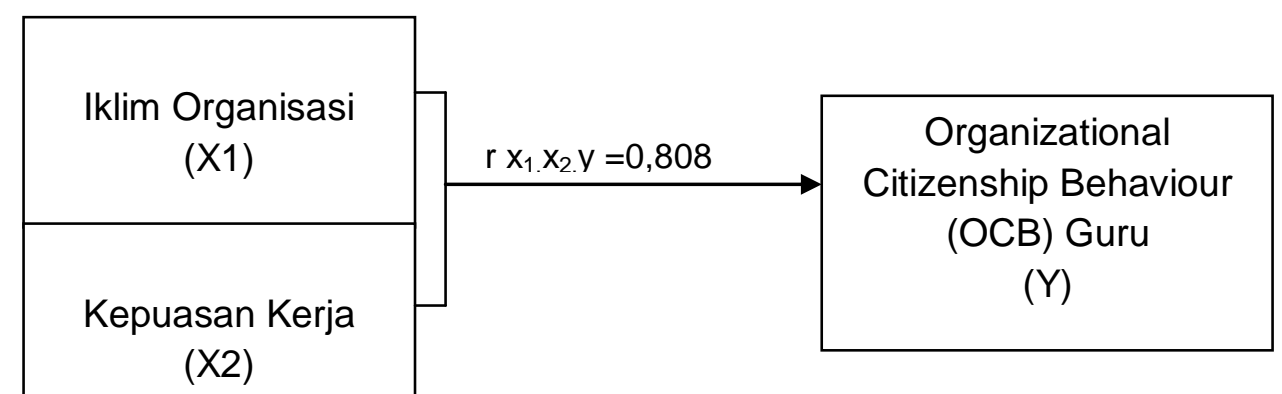

\section{Gambar 4 Korelasi hubungan antar variabel penelitian}

\section{H. Pembahasan}

Hasil statistik tersebut menunjukkan bahwa korelasi berganda iklim organisasi (X1) dan Kepuasan Kerja (X2) secara bersama-sama dengan Organizational Citizenship Behaviour (OCB) Guru (Y). Hasil penelitian menunjukkan bahwa terdapat hubungan yang positif antara iklim organisasi dan kepuasan kerja secara bersama-sama Organizational Citizenship Behaviour (OCB) guru. Kekuatan hubungan antara iklim organisasi (X1) dan kepuasan kerja (X2) dengan Organizational Citizenship Behaviour (OCB) guru (Y) kekuatan hubungan antara kepuasan kerja dengan Organizational Citizenship Behaviour (OCB) guru dengan koefisien determinasi $\left(r^{2}\right)$ antara kepuasan kerja (X2) dengan Organizational Citizenship Behaviour (OCB) guru (Y) sebesar 0,808 atau 80,8 $\%$ sedangkan sisanya $19,2 \%$ dipengaruhi oleh faktor lain.

Uji regresi berganda antara iklim organisasi dan kepuasan kerja dengan Organizational Citizenship Behaviour (OCB) guru MIN Se Kota Pekanbaru dapat dilihat pada persamaan regresi adalah sebagai berikut $\ddot{\mathrm{Y}}=$ $0.052+1,153 \mathrm{X}_{1}+0,164 \mathrm{X}_{2}$. Hasil statistik tersebut menunjukkan bahwa iklim organisasi dan kepuasan kerja pada konstanta 0.052 memberi kontribusi meningkatkan Organizational Citizenship Behaviour (OCB) guru sebesar 1,153 dan 0,164 pada guru MIN Se Kota Pekanbaru.

Hasil statstik tersebut menunjukkan bahwa secara bersamasama iklim organisasi dan kepuasan kerja memberikan kontribusi yang sangat signifikan terhadap Organizational Citizenship Behaviour (OCB) guru, artinya semakin baik iklim organisasi dan kepuasan kerja, maka semakin baik pula Organizational Citizenship Behaviour (OCB) guru MIN Se Kota Pekanbaru. Sebaliknya semakin buruk iklim organisasi dan kepuasan kerja, maka semakin buruk pula Organizational Citizenship Behaviour (OCB) guru MIN Se Kota Pekanbaru.

Hasil penelitian ini sesuai dengan hasil penelitian yang dilakukan oleh Rosita Bestiana dengan judul penelitian "Hubungan Kepuasan Kerja, iklim organisasi Dan Komitmen Normatif Dengan Organizational Citizenship Behaviour (OCB) Guru SMAN 1 Medan. Hasil analisis regresi menyatakan bahwa seluruh variabel 
yang dianalisis dengan menggunakan uji $\mathrm{F}$ dan hasilnya diperoleh $\mathrm{Fh}>\mathrm{Ft}$. Ini menunjukkan bahwa kepuasan kerja guru, iklim organisasi dan komitmen normatif dapat dijadikan sebagai faktor dalam menentukan Organizational Citizenship Behaviour (OCB) guru di SMA Negeri 1 Medan. ${ }^{21}$

Namun berbeda dengan penelitian mengenai Iklim Organisasi dengan perilaku Organizational Citizenship Behaviour (OCB) menyatakan bahwa iklim organisasi tidak memiliki hubungan yang cukup signifikan. Artinya semakin tinggi nilai iklim organisasi karyawan maka semakin rendah pula perilaku Org anizational Citizenship Behaviour (OCB) karyawan. ${ }^{22}$ Sedangkan kepuasa kerja memiliki hubungan signifikan terhadap perilaku Organizational Citizenship Behaviour (OCB) karyawan. Apabila kepuasan kerja karyawan tinggi maka semakin tinggi pula perilaku Organizational Citizenship Behaviour (OCB) karyawan. ${ }^{23}$

Jadi, pada dasarnya akan selaras dengan tujuan dari administrasi pendidikan, sebab tujuan dari administrasi pendidikan itu sendiri ialah meninjau setiap komponen-komponen pendidikan serta memperbaiki sistem dan hubungannya, seperti iklim organisasi, kepuasan kerja dan Organizational Citizenship Behaviour (OCB) guru merupakan bagian dari komponen-komponen tersebut, seperti

${ }^{21}$ M. Lubis. Pengaruh Iklim Organisasi Dan Komitmen Organisasi Terhadap Pembentukan Organizational Citizenship Behaviour (OCB) Kayawan Dalam Ranka Peningkatan Kerja. EJurnal Apresiasi Ekonomi Vol.3, No. 2. 2015.

22 Imam Aryansah \& Erika Setyanti K. Iklim Organisasi Dan Kualitas Kehidupan Kerja Karyawan. Jurnal Humanitas, Vol. X No.1 Januari 2013, Universitas Islam Negeri Sunan Kalijaga, Yogyakarta. 2013.

${ }^{23}$ Ibid yang penulis simpulkan di atas bahwa semakin baik iklim organisasi dan kepuasan kerja guru maka akan sangat berpengaruh dengan Organizational Citizenship Behaviour (OCB) guru itu sendiri. ${ }^{24}$ Jadi hubungan dan kerja sama harus terjaga dan semakin ditingkatkan dengan harapan pencapian visi dan misi pendidikan itu sendiri.

\section{Kesimpulan}

Kajian ini telah memberi gambaran yang jelas dan menyeluruh mengenai pengaruh faktor iklim organisasi, kepuasan kerja dan Organizational Citizenship Behaviour (OCB) guru MIN Se Kota Pekanbaru. Analisis kajian memiliki makna bagi guru bahwa perlu adanya iklim organisasi yang bagus dan kepuasan kerja yang bagus untuk bekerja sepenuh hati di sekolah. Dapatan hasil penelitian dengan penelitian terdahulu memiliki berbedabeda pendapat. Namun peneliti tetap konsisten dengan hasil penelitian yang telah diteliti. Maka Peneliti mengambil kesimpulan, bahwa faktor iklim organisasi dan kepuasan kerja mempengaruhi Organizational Citizenship Behaviour (OCB) guru MIN Se Kota Pekanbaru. Namun masih ada faktor lain yang mempengaruhi Organizational Citizenship Behaviour (OCB) guru MIN Se Kota Pekanbaru. Tentunya perlu diberikan program pelatihan dan family gathering untuk menjadi tinggi kepuasan kerja dan adanya iklim yang positif untuk bekerja sepenuh hati.

\section{J. Pendanaan}

\footnotetext{
24 Fatwa Tentama. Peran Kepuasan Kerja Terhadap Kinerja Pada Guru Pegawai Negeri Sipil (PNS) Di Yogyakarta. Jurnal Online Vol. 14, No. 1 (2015), Fakultas Psikologi Undip. 2015 .
} 
Karya ini adanya karena didukung oleh bantuan dari lembaga penelitian dan pengabdian kepada masyarakat (LP2M) UIN Suska Riau

\section{Daftar Pustaka}

Afriani, Fitri. 2013. Pengaruh Iklim Organisasi terhadap Kepuasan Kerja Pegawai pada Kantor Kecamatan Kepenuhan Hulu. Jurnal Mahasiswa Prodi SI Manajemen, 1 (1), h:1-23.

Ayudiarini, Natassia. 2010. Pengaruh Iklim Organisasi dan Pengembangan Karir Terhadap Kepuasan Kerja. Gunadarma University E-Paper,1 (2) h:116

As'ad, Muhammad 2004. Pikologi Industri. Liberty. Yogyakarta.

Brahmasari Ida Ayu, 2008. Pengruh Motivasi Kerja, Kepemimpinan Dan Budaya Organisasi Terhadap Kepuasan Kerja Karyawan Seta Dampaknya Pada Kinerja Perusahaan, jurnal manajemen dan kewirausahaan, vol. 10, No. 2 September 2008:124-135, Pasca sarjana universitas 17 agustus surabaya, surabaya.

Brahmana, S.S. \& Sofyandi, H. (2007). Transformational Leadership dan Organization Citizenship Behavior di Utama. Laporan Penelitian. Tidak diterbitkan.

Dharing Meylandani.,2013. Hubungan Antara Iklim Organisasi Dan Organizational Citizens Behavioral (Ocb) Pada Perawat Rsud Kanjuruhan Kepanjen Kabupaten Malang, dalam Jurnal Online Vol.1, No.1 (2013), Fakultas Pendidikan Psikologi Universitas Negeri Malang, Malang

Eddy Triyono., 2015. Determinasi Iklim Organisasi Terhadap Golongan
Kepangkatan dalam Pengembangan Profesional Dosen, dalam Jurnal TEKNIS, Volume 10, Nomor 2, Agustus 2015 : 102 -106, Politeknik Negeri Semarang, Semarang.

Fatwa Tentama., 2015. Peran Kepuasan Kerja Terhadap Kinerja Pada Guru Pegawai Negeri Sipil (PNS) Di Yogyakarta. Jurnal Online Vol. 14, No. 1 (2015), Fakultas Psikologi Undip

Herman., 2014. Pengaruh Iklim Organisasi dan Kepuasan Kerja Terhadap Kinerja Guru.Jurnal Administrasi Pendidikan Pascasarjana Universitas Syiah Kuala Vol4, No.2

Imam Aryansah \& Erika Setyanti K., 2013. Iklim Organisasi Dan Kualitas Kehidupan Kerja Karyawan. Jurnal Humanitas, Vol. X No.1 Januari 2013, Universitas Islam Negeri Sunan Kalijaga, Yogyakarta.

Kaswan. 2015. Sikap Kerja: Dari Teori dan Implementasi sampai Bukti. Alfabeta. Bandung.

M. Lubis., 2015. Pengaruh Iklim Organisasi Dan Komitmen Organisasi Terhadap Pembentukan Organizational Citizenship Behaviour (OCB) Kayawan Dalam Ranka Peningkatan Kerja. E-Jurnal Apresiasi Ekonomi Vol.3, No. 2

Prihatsanti, U (2010). Hubungan Antara Iklim Organisasi Dan Organizational Citizenship Behavior (OCB) Pada Guru SD Negeri Di Kecamatan Mojolaban Sukoharjo. Jurnal Psikologi Undip Vol. 7, No.1, April 2010. 11-17

Robbins, Stephen P. 2006. Perilaku Organisasi. Edisi Bahasa Indonesia. PT. Indeks. Jakarta. 
Triatna, Cepi. (2015). Perilaku

Organisasi dalam Pendidikan.

Bandung:ROSDA

Ulfiani. 2014, Kepuasan Kerja dan

Organizational Citizenship

Behaviour Pada Guru

Madrasah Aliyah Madani

Alaudin Paopao Gowa

Sulawesi Selatan. Jurnal

Analisa Vol. 21, No.1

Vannecia dkk., 2013. Pengaruh

Kepuasan Kerja Dan Loyalitas

Kerja Terhadap Organizational

Citizenship Behaviour Pada

Karyawn PT. Surya Timur

Jatim. AGORA Vol.1, No.1

Yuniar dkk., 2011. Hubungan Kepuasan

Kerja dan Resiliensi dengan

Organizational Citizenship

Behaviour (OCB) Pada

Karyawan Kantor Pusat PT.

BPD BALI. Jurnal Psikologi

Undip Vol.9, No.1

Yusuf, A.M. 2013. "Metodologi

Penelitian: Kuantitatif, Kualitatif

dan Penelitian Gabungan”.

Padang: UNP Press 